\title{
Unravelling Mickey Mouse: The Effect of Supply Chain Position and Organisational Slack on the Uneven Balance of Sustainability Dimensions
}

\author{
Sini Laari ${ }^{1,2, *(\mathbb{D}}$, Tomi Solakivi ${ }^{1}$, Anu Bask ${ }^{1} \mathbb{1}$, Juuso Töyli ${ }^{1,3}$ and Lauri Ojala ${ }^{1}$ \\ 1 Operations and Supply Chain Management, University of Turku, 20500 Turku, Finland; \\ tomi.solakivi@utu.fi (T.S.); anu.bask@utu.fi (A.B.); juuso.toyli@utu.fi (J.T.); lauri.ojala@utu.fi (L.O.) \\ 2 Turku Institute for Advanced Studies, University of Turku, 20500 Turku, Finland \\ 3 Department of Communications and Networking, Aalto University, 02150 Espoo, Finland \\ * Correspondence: sini.laari@utu.fi
}

check for updates

Citation: Laari, S.; Solakivi, T.; Bask, A.; Töyli, J.; Ojala, L. Unravelling Mickey Mouse: The Effect of Supply Chain Position and Organisational Slack on the Uneven Balance of Sustainability Dimensions. Sustainability 2021, 13, 13623. https: / / doi.org/10.3390/ su132413623

Academic Editor: Alessio Ishizaka

Received: 1 November 2021

Accepted: 8 December 2021

Published: 9 December 2021

Publisher's Note: MDPI stays neutral with regard to jurisdictional claims in published maps and institutional affiliations.

Copyright: (c) 2021 by the authors. Licensee MDPI, Basel, Switzerland. This article is an open access article distributed under the terms and conditions of the Creative Commons Attribution (CC BY) license (https:/ / creativecommons.org/licenses/by/ $4.0 /)$.

\begin{abstract}
This paper contributes to a less-studied area on how a firm's position in the supply chain influences triple-bottom-line considerations in strategic decision making. We also contribute to previous research on a nuanced understanding of unabsorbed organisational slack as an antecedent to the triple-bottom-line dimensions of sustainability. The research data comprises survey data and financial reporting data from 508 manufacturing and trading firms operating in Finland, divided among four supply chain tiers. The economic dimension dominates the decision making on all tiers, followed by social and environmental considerations, resembling the shape of Mickey Mouse. Unabsorbed organisational slack is negatively related to the importance of economic considerations and positively related to environmental considerations. The results help firms in evaluating their position in terms of sustainability and in their redesigning efforts accordingly. The findings will also be useful in terms of promoting sustainability practices among supply chain members and policymakers in their practical efforts towards sustainable development.
\end{abstract}

Keywords: sustainable supply chain management; supply chain position; sustainability dimensions; organisational slack; stakeholder theory; triple bottom line

\section{Introduction}

Organisations that attempt to incorporate sustainability into their supply-chain practices face a number of contradictory objectives, such as short-term profit maximisation and long-term environmental and social sustainability [1]. The majority of companies seem to behave in an instrumental way, favouring the economic dimension over the environmental and social [2]. Hence, they tend to assign sustainability a secondary role in terms of optimising profits and managing risks [3]. Despite the trade-offs faced by companies, relatively few articles have investigated how important firms perceive the three dimensions of sustainability vis-à-vis each other [4].

The aim of this study is to examine two factors that may explain the relative importance of the economic, environmental, and social sustainability dimensions in strategic decision making: first, the supply chain position of the focal firm [5] and second, organizational slack [6]. More specifically, a firm's level of sustainability is influenced by its visibility to its stakeholders, and therefore stakeholder pressures vary from one supply-chain tier to another [5,7]. Firms that operate in close proximity to the end consumer are most visible because of brand recognition and the general presence of their products $[5,8]$. Those that are under closer public scrutiny are, therefore, more likely to face sustainability pressures than their less familiar counterparts, which motivates them to behave in a more sustainable way [9]. For example, high-profile companies such as Apple, H\&M and Lidl have been criticised for abusive behaviour in their supply chains, such as causing environmental 
damage or showing ignorance of human rights and labour standards [10-12]. On the contrary, upstream suppliers have fewer incentives to develop proactive sustainability approaches and thus prioritise economic considerations [5]. As downstream firms are oftentimes held accountable for sustainability infringements, they are likely to engage in more proactive sustainability strategies to counter potential risks, such as supplier collaboration [8].

The second factor examined in this study is organisational slack [6]. The organizational slack perspective suggests that firms that are financially superior to their peers have a surplus of resources that can be allocated to conducting environmental practices $[6,13,14]$. Our study regards organisational slack as unabsorbed financial resources [15] that can be deployed in sustainability initiatives. They can absorb the costs of voluntary environmental and social policies, serve as a buffer against the uncertainty of investments, or provide opportunities to undertake innovations, for example $[14,16]$. Firms with little or no slack, in turn, are less likely to implement sustainable practices due to resource constraints [17].

The following two research questions are addressed in this study:

RQ1: How does a firm's position in the supply chain affect the importance of each three dimensions of sustainability?

RQ2: How does organisational slack affect the importance of each sustainability dimension?

Our contribution to the literature on the antecedents of sustainability is two-fold. First, we enhance the understanding of how a firm's position in the supply chain influences economic, environmental and social considerations in medium- and long-term decision making. This study thereby contributes to the timely topic of multi-tier supply chain management e.g., $[18,19]$ and fills the gap in knowledge about the role of supply chain position on social dimension and economic dimension [20]. The "firm's position" refers to the different tiers in the supply chain. Despite extensive research on sustainability, the relative importance of environmental and social dimensions remains largely unknown $[4,21]$. Second, we provide a nuanced understanding of unabsorbed organisational slack as an antecedent to the three dimensions of sustainability. Previous research has mainly focused on slack as an antecedent to corporate environmental performance [22], and therefore the organisational slack view can also be applied to other dimensions of sustainability. Furthermore, the majority of previous research has focused on large, publicly listed companies whereas this paper studies firms of diverse sizes. Given that smaller firms are likely to have scarce resources, it can be expected that these firms can particularly benefit from financial slack [23]. Overall, the results shed light on whether the instrumental behaviour prevails in strategic decision making, and on the underlying financial drivers among retailers, wholesalers and manufacturers, as well as suppliers of materials and components.

Furthermore, many previous empirical studies have relied on simultaneous measurement of environmental and financial performance, which does not allow establishing causal linkages, but mere associations [22]. Recently, there has been an increasing number of meta-analyses and studies addressing endogeneity on the environmental performancefinancial performance linkage, but they point out that there is room for research on a more fine-grained level that takes into account various contingencies, e.g., [24-27]. This paper contributes to the sustainable supply chain management literature through the analysis of survey data from different tiers of the chain combined with financial reporting data from three years. The dataset comprises 508 manufacturing and trading firms operating in Finland. The results help firms in evaluating their position in terms of sustainability, and in their redesigning efforts accordingly. The findings will also be useful in terms of promoting sustainability practices among supply-chain members and policymakers in their practical efforts towards sustainable development. 


\section{Theoretical Underpinnings}

\subsection{Sustainability and Supply Chain Position}

Stakeholders are defined by Freeman [28] (p. 25), as "any group or individual who can affect or is affected by the achievement of the firm's objectives". The stakeholder theory identifies a number of primary (e.g., customers, suppliers, employees, top managers and shareholders) and secondary stakeholders' (e.g., governments, competitors, investors, NGOs and the media) intent on promoting environmental and social sustainability [29]. However, interest in the environmental, social and economic dimensions varies among stakeholder groups [29], which in turn vary in their importance to and influence over focal firms [30]. The salience of stakeholders' claims depends on three factors: stakeholder's power, the legitimacy of its claim and the urgency of these claims [31,32]. Thus, stakeholder influence may vary depending on the industry, the type of supply chain, the size and location of the organisation and the level of internationalisation, for example [33,34].

Stakeholder theory can be divided into two main streams: normative and instrumental stakeholder theory [35]. The normative stakeholder theory builds on normative-ethical foundations and views satisfying the interests of multiple stakeholders groups as "the right thing to do" [36]. This study adopts an instrumental stakeholder perspective. According to the instrumental stakeholder theory firms can benefit from addressing the social and environmental concerns of stakeholders [36]. Firms are dependent on the input that stakeholders provide, and therefore they can either facilitate or hamper the pursuit of economic goals [37]. With regards to sustainability, stakeholders can provide help, develop policies, commit resources to evaluation and monitoring and identify development opportunities in the firm's supply chain [32]. Ignoring stakeholder demands may have dire consequences: customers could boycott products, investors may sell their shares, and employees could withhold loyalty [38].

Firms in different positions in the supply chain are subject to varying levels of stakeholder pressure and perceived importance [5,7]. These firms face structurally and contextually different stakeholder environments in terms of laws, regulations and public evaluations, and consequently develop diverse green supply chain management capabilities $[7,39]$. Specifically, firms close to the end consumer are more visible $[5,34]$ and are typically held liable for their upstream partners [8]. This chain liability effect places firms at risk of reputational and financial damage, which increases their willingness to invest in sustainable supply chain management (SSCM) as a countermeasure [5,40]. In contrast, upstream suppliers place less emphasis on environmental and social issues in their strategic decision making compared to downstream firms $[5,33,41]$. This strongly indicates that the firm's position in the supply chain has an impact on how it evaluates the importance of sustainability in its business operations.

\subsection{Organisational Slack and Sustainability}

Slack refers to excess resources available to an organisation during a given planning cycle [42]. Researchers have divided organisational slack into absorbed and unabsorbed slack $[15,43]$. Absorbed slack is tied to specific operations and cannot be easily deployed elsewhere whereas unabsorbed slack comprises currently uncommitted resources that can be readily allocated to a range of activities $[14,42,43]$. We follow the example of studies that consider financial slack resources as a proxy measure of excess resources within an organization [13].

According to the slack resource view, managers consider investments in sustainability only if there are enough financial resources [44,45]. Firms with abundant resources will have more strategic choices and are, therefore, more willing to undertake sustainable actions [46,47]. Excessive resources permit firms to seek more innovative solutions [14]. Unabsorbed slack enables firms to pursue sustainability even if the projects do not pay off at the early stages [14]. The view is consistent with Waddock and Grave's [6] "virtuous cycle" where superior financial performance allows firms to invest in environmental performance, which in turn results in better financial returns. Nevertheless, the assumption 
of the universal validity of the slack resource view has recently been challenged because of inconsistent results $[3,14]$.

\section{Hypothesis Development}

Following previous studies $[14,41,47]$, we posit that unabsorbed financial slack contributes to the relative importance of sustainability dimensions in decision making because it can be deployed for exploring novel strategic directions, such as sustainability improvements. If managers are concerned about the day-to-day survival of the firm, there are multiple tasks that compete for managers' attention [48], leaving limited time for sustainability issues. Firms with limited resources are, therefore, more likely to invest in what they consider fundamental for their survival [49]. In such situations, sustainability improvements are unlikely to be high on the agenda [9].

When firms accumulate more slack, the conflicts over budget are less intense and managers are free to explore other options [50], such as potentially costly and long-term sustainability investments [45]. Conversely, when companies do not need to use slack solely for economic survival, the primacy of profit generation may be replaced by wider sustainability considerations [51]. Recent research found that resource slack plays a more powerful role in strengthening SSCM compared to top management support [52]. Unabsorbed slack helps firms to meet better various stakeholder demands [46]. Unabsorbed slack resources may induce environmental innovation and allow firms to engage in advanced pollution prevention strategies [14]. Slack resources can also be used for developing a safe working place, in the form of training for operational workers, hiring safety or ergonomic experts or developing innovative new processes [16], as an example. In light of the above discussion, we posit the following hypotheses:

Hypothesis 1a (H1a). Unabsorbed organizational slack is negatively related to the importance of the economic dimension of sustainability in strategic decision making.

Hypothesis $\mathbf{1 b} \mathbf{b} \mathbf{H 1 b})$. Unabsorbed organizational slack is positively related to the importance of environmental and social dimensions of sustainability in strategic decision making.

It is implied in instrumental stakeholder theory that because upstream suppliers are not under public scrutiny [9] they are not incentivised to emphasise environmental and social issues in their strategic decision making $[5,53]$. On the contrary, they may be under financial pressure from their downstream customers. If one customer accounts for a major proportion of a given supplier's sales, for example, the supplier is likely to be financially quite dependent on that customer $[54,55]$. Suppliers may, therefore, be willing to go great lengths to satisfy their customers, guaranteeing high levels of service, allocating materials and capacity or accepting less advantageous payment terms [54,56]. As Lanier et al. [55] show, for example, large buying firms exploit their power in the supply chain to meet or beat their financial objectives.

According to Gereffi and Lee [57], retailers wield significant power in global supply chains because of a shift in drivers from producers to buyers. For example, Tesco and other firms from different industries have been accused of squeezing their suppliers to support its short-term profit margins, a phenomenon referred to as supplier exploitation [58]. Buyers may seek lower costs while simultaneously persuading suppliers to comply with higher environmental and social standards that may generate additional costs [59]. For example, trade credit adjustments are passed along the supply chain, "making less powerful members bear the burden" [56] (p. 377). This situation leads to the unequal distribution of respective benefits, risks and investments across the companies involved. Given the inherent tensions between contradictory sustainability objectives, decisions are ultimately judged through the lens of profit maximisation [60]. Priority in investment decisions is given to economic considerations because of price pressures and high levels of competition [61]. Consequently, we posit the following hypothesis: 
Hypothesis 2 (H2). The relative importance of the economic dimension of sustainability in strategic decision making grows towards the upstream of the supply chain.

The analysis of supplier development trade-off preferences by Rogers et al. [62] revealed that decision makers valued improvements in supplier costs savings (economic dimension) and injury reduction (social dimension) equally, over emissions reductions (environmental dimension). Two recent studies have focused on how the willingness to purchase a product is related to specific sustainability dimensions. Goebel et al. [63] found that purchasing managers were willing to pay the highest price premium for good labour conditions. Nichols et al. [64], in turn, studied the impact of supply chain news on consumers' perceptions of product quality and found that compared to practically salient (i.e., economic) news emotionally salient news related to social or environmental issues created a stronger impact on consumers' purchase interest.

This may be because, as Busse et al. [11] (p. 322) put it: “ ... social sustainability issues refer to human fates, whereas environmental issues concern only 'numbers' which are difficult to assess". Previous research has linked this with psychological distance, i.e., "a subjective experience that something is close or far away from the self, here, and now" [65] (p. 440). Psychological distance is typically measured using four key dimensions: geographic/spatial (e.g., near or remote locations), temporal (e.g., current or future events), social (e.g., best friend or a stranger) and hypothetical/uncertainty (e.g., likelihood of happening) [66]. For example, climate change has been claimed to be psychologically distant on all these dimensions which is why many people do not behave in a sustainable fashion [67]. In the supply chain context, Carter et al. [68] suggest that supplier sustainability may be overlooked because it occurs at a distance from the buying company. Catlin et al. [69] found that consumers associated social sustainability with affective, short-term, and local factors, whereas environmental sustainability was more psychologically distant and, therefore, less likely to motivate a behavioural change. Managers perceive emissions released by suppliers to be "far off" and unlikely to pose any financial threat while worker injuries at suppliers' facilities are considered more immediate and their impact can be more easily quantified [62]. Especially, if the firm operates in an environment where there is state orchestration of social sustainability, extensive rights and strong trade unions, institutional traditions encourage good social performance [70]. Based on the above discussion, we argue that environmental issues will have a larger psychological distance from supply chain decision makers than social issues, and that this basic principle equally applies to all tiers of the supply chain. Hence, we propose that:

Hypothesis 3 (H3). The social dimension of sustainability has more influence on strategic decision making than the environmental dimension in each position on the supply chain.

Figure 1 below depicts the research framework of this study. To test $\mathrm{H} 2$ and $\mathrm{H} 3$, firms are divided among the four tiers of the supply chain: retail (R), wholesale (W), manufacturing of raw materials and components (M1), and manufacturing of end products (M2). The division is explained in more detail in the materials and methods chapter. 


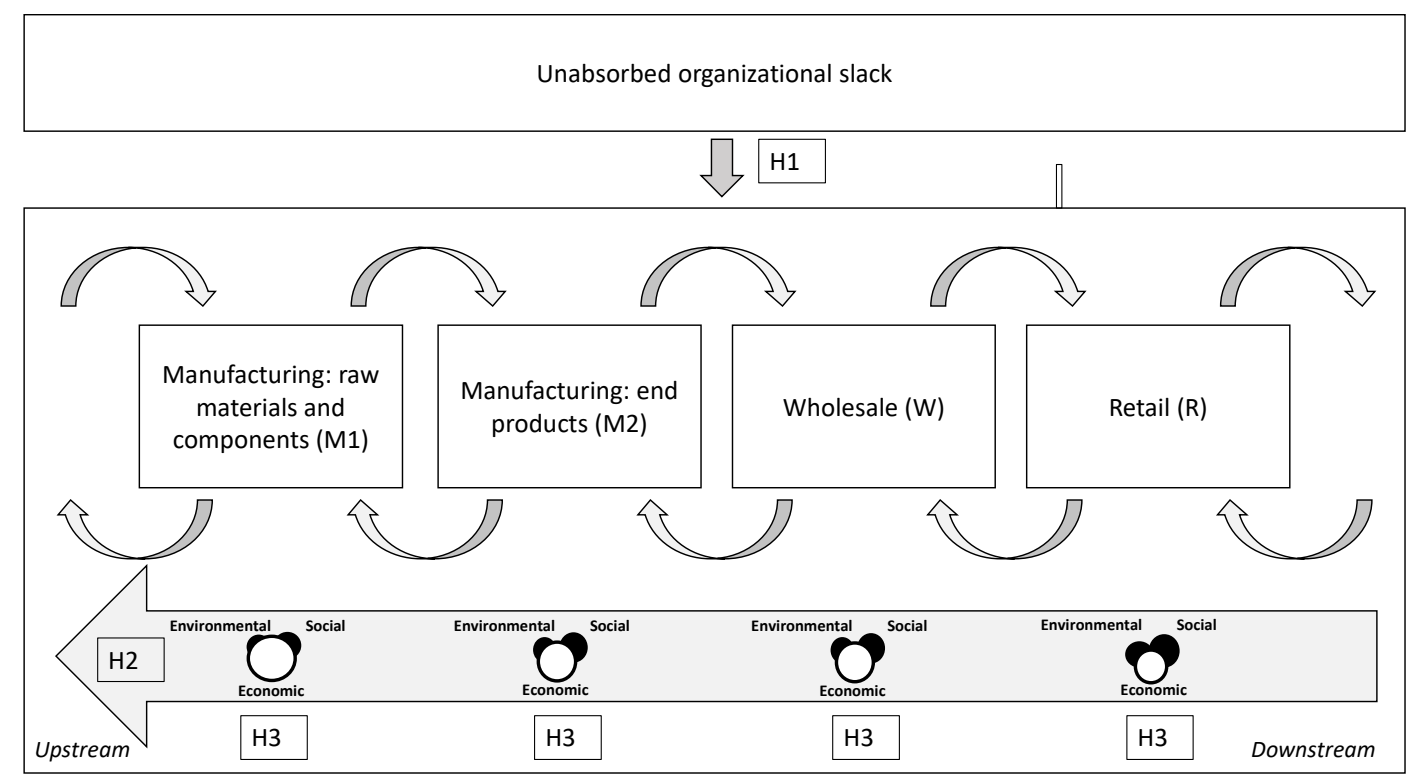

Figure 1. The research framework.

\section{Materials and Methods}

\subsection{Sampling and Data Collection}

The dataset analysed in this article was collected as part of the Finland State of Logistics 2018 survey [71] The web-based questionnaire data was gathered in the year 2018. Invitation to participate was sent to 27,598 emails, out of which 2001 answered the survey. Hence, the response rate was 7.3 percent, which may limit the generalizability of the findings. However, Wagner and Kemmerling [72] reviewed 229 survey studies in the field of logistics, including the respective response rates. Based on their results, the response rate of the Finland State of Logistics 2018 survey is well in line with other surveys on a similar scale. As each respondent could be identified by a unique questionnaire link, a business identity code could be matched with each response. If there were more than one answer from the same organization, the most complete was chosen. The sample (508) was limited to manufacturing and trading companies who provided complete responses to all the questions included in the analysis. Seventy-six percent of respondents were from top management, and the remaining 24 percent were middle management, experts and other staff.

The survey data was combined with financial reporting based data from the year 2016 to 2018. This financial data for organizational slack measures were collected from Voitto+ database, based on business identity codes. Voitto+ is a database containing financial data from more than 100,000 Finnish firms. Using an external database also decreases the risk of common method variance.

\subsection{Variables}

The firms were divided among the four tiers of the supply chain based on their sector using the NACE 2008 industry classification. A detailed breakdown into industries is shown in Appendix A. The retail (R) and wholesale (W) tiers comprise firms classified as operating in the retail and wholesale trades, respectively. Manufacturing firms were divided into manufacturers of raw materials and components (M1) and manufacturers of end products (M2), based on the latest input-output tables (2015) of the Finnish manufacturing industry.

Dividing the manufacturing firms into these two separate tiers required analysis of the forward-backward linkages of the industries, following the examples of Midmore [73], Hautala et al. [74] and Lorentz et al. [56]. The linkage concept is based on the notion of 
industrial interdependence [75]: the higher the share of forward linkages in an industry, the higher is the share of its products being sold to intermediate users. In this research, the manufacturing industries were divided into two tiers, M2 and M1, based on Jones's [75] forward-linkage indicators of individual industries. The M1 group includes mining and quarrying, printing and recording services, the manufacture of basic metals, and of pulp and paper products, among other things. The M2 tier contains industries such as the manufacture of basic pharmaceutical products and preparations, furniture and other manufactured goods, and other transport equipment.

In order to measure the importance of sustainability on the companies' decision making, we draw on previous sustainability research and asked the respondents to estimate on single items how much (between $0 \%$ and $100 \%$ ) their companies took into account the three dimensions of sustainability in their midterm and long-term strategic decision making. The items are presented in Table 1 . The three dimensions representing triple bottom line were: (1) economic factors such as profitability and competitiveness; (2) environmental factors such as carbon footprint, other environmental impacts and a life-cycle approach; (3) social factors such as the well-being of workers, work safety and human rights in the company's supply chain. The examples were attached to the items to make the indicators sufficiently concrete and to give the respondents an idea of various issues that may be related to each dimension. These items are used as dependent variables in the analyses. The simplicity and conciseness of the survey instrument can be expected to contribute to completing the questionnaire [76]. To mitigate the consistency motive, the items were placed randomly in the questionnaire, e.g., [77].

Table 1. Measurement items.

\begin{tabular}{|c|c|c|}
\hline & Measurement Item & Adapted from \\
\hline Sustainability & $\begin{array}{l}\text { Please assess the importance of the } \\
\text { following three factors in the mid- and } \\
\text { long-term strategic decision making in } \\
\text { your company (total 100\%): } \\
\text { (a) Social factors (e.g., well-being of } \\
\text { workers, work safety, human rights in } \\
\text { the supply chain) } \\
\text { (b) Environmental factors (e.g., carbon } \\
\text { footprint, other environmental impacts, } \\
\text { life-cycle approach) } \\
\text { (c) Economic factors (e.g., profitability, } \\
\text { competitiveness) }\end{array}$ & $\begin{array}{l}\text { Marshall et al. [78] } \\
\text { Mani et al. [79] }\end{array}$ \\
\hline Unabsorbed slack & 3-year average current ratio (2016-2018) & Tan \& Peng [38] \\
\hline Firm size & $\begin{array}{l}4 \text { categories: micro, small, medium } \\
\text { and large }\end{array}$ & European Commission [80] \\
\hline $\begin{array}{c}\text { Share of } \\
\text { international sales }\end{array}$ & $0-100 \%$ & Lorentz et al. [56] \\
\hline
\end{tabular}

In this study, we measure organizational slack as a firm's current ratio (current assets/current liabilities) [14]. This measure conceptualises organisational slack as available or unabsorbed slack, i.e., liquid resources that can be easily deployed elsewhere [38]. We subtract the median industry (at a NACE 3-level) current ratio from a firm's current ratio to address potential industry differences [14]. To capture a longer time horizon, we calculate a 3-year average current ratio (2016-2018) for each firm.

In addition, two control variables were used. Firm size was measured as a 4-category variable. Firms were divided into micro-sized $(n=282)$, small $(n=123)$, medium-sized $(n=59)$ and large $(n=44)$ based on the turnover criteria of the European Commission [80]. The size categories were used to create three dummy variables. The share of international sales $(0-100 \%)$ was measured as a continuous variable based on self-reported estimates [51]. 
Because our study employs single indicators instead of latent constructs, we used conventional analyses instead of structural equation modelling. Specifically, ANOVA and Kruskall-Wallis test were used to test for differences between supply chain tiers while hierarchical regression analysis was employed to assess the relationship between current ratio and the three dimensions of sustainability, controlling for firm size and degree of internationalization [56].

\section{Results}

First, an ANOVA was conducted to test for differences in current ratio between tiers. There were no statistically significant differences. Next, a regression analysis to assess the relationship between organisational slack and dimensions of sustainability was conducted hierarchically. Step 1 includes only control variables (firm size and degree of internationalisation), and organisational slack measured as 3-year average current ratio was added in step 2. Table 2 shows the results of the regression analysis.

Table 2. Regression results.

\begin{tabular}{|c|c|c|c|c|c|c|c|c|}
\hline $\begin{array}{c}\text { Dependent } \\
\text { Variable }\end{array}$ & Step & $\begin{array}{c}\text { Size } \\
\text { Dummy } \\
\text { Small }\end{array}$ & $\begin{array}{c}\text { Size } \\
\text { Dummy } \\
\text { Medium }\end{array}$ & $\begin{array}{c}\text { Size } \\
\text { Dummy } \\
\text { Large }\end{array}$ & Internationalisation & $\begin{array}{c}\text { Current } \\
\text { Ratio }\end{array}$ & $\mathbf{R}^{2}$ & $\underset{R^{2}}{\text { Adj. }}$ \\
\hline Economic & 1 & 3.540 & 1.768 & -4.964 & 0.019 & & 0.017 & 0.005 \\
\hline sustainability & 2 & 3.011 & 1.160 & -5.848 & 0.020 & $-0.422 *$ & 0.029 & 0.014 \\
\hline Environmental & 1 & -0.521 & 1.698 & 5.440 & -0.006 & & 0.030 & 0.018 \\
\hline sustainability & 2 & -0.111 & 2.169 & $6.125^{* *}$ & -0.006 & $0.327^{* *}$ & 0.057 & 0.042 \\
\hline Social & 1 & -3.019 & -3.466 & -0.476 & -0.014 & & 0.014 & 0.002 \\
\hline sustainability & 2 & -2.900 & -3.329 & -0.277 & -0.014 & 0.095 & 0.016 & 0.001 \\
\hline
\end{tabular}

The coefficients of the control variables were mostly non-significant. Large firms were inclined to have a higher emphasis on environmental sustainability, but otherwise, firm size did not play a role. The degree of internationalisation was not significant either.

The coefficients of the current ratio have the expected signs. Unabsorbed slack has a negative effect $(b=-0.400, p=0.060)$ on the importance of the economic dimension. Hypothesis $1 \mathrm{a}$ is therefore supported. Unabsorbed slack has a positive effect on the importance of environmental $(b=0.312, p=0.004)$ and social sustainability $(b=0.088$, $p=0.559)$, but the relationship between current ratio and environmental sustainability is only statistically significant. Hence, hypothesis $1 \mathrm{~b}$ is partially supported. The control variables of firm size and degree of internationalisation are not statistically significant.

Table 3 summarises the respondents' views on the extent to which their respective firms take into account economic, social and environmental factors in their midterm and long-term decision making. Economic factors seem to dominate on all the tiers of the supply chain: the lowest proportion being $63.71 \%$ on $\mathrm{M} 2$ and the highest $(68.75 \%)$ on $\mathrm{W}$, whereas the second lowest $(63.73 \%)$ concerns the choice of M1. The descriptive analysis indicates no identifiable trend or differences in how the different tiers of the supply chain consider the importance of different factors of the triple bottom line. A large size of the firm was found to be connected with environmental sustainability. This may be because large firms are more subject to public pressure and expected to take responsibility for the whole supply chain [36]. They also benefit from more resources, in terms of skills, for example. The data was further subjected to both ANOVA the non-parametric Kruskal-Wallis test. No statistically significant differences between the different tiers of the supply chain could be identified in any of the analysed factors. Therefore, Hypothesis 2 was not supported. 
Table 3. To what extent do firms take into account economic, social and environmental factors in their midterm and long-term decision making?

\begin{tabular}{|c|c|c|c|c|c|c|c|c|}
\hline & \multicolumn{2}{|c|}{$\begin{array}{l}\text { Raw Materials and } \\
\text { Components } \\
(n=129)\end{array}$} & \multicolumn{2}{|c|}{$\begin{array}{l}\text { End Products } \\
\qquad(n=149)\end{array}$} & \multicolumn{2}{|c|}{$\begin{array}{l}\text { Wholesale } \\
\qquad(n=91)\end{array}$} & \multicolumn{2}{|c|}{$\begin{array}{c}\text { Retail } \\
(n=139)\end{array}$} \\
\hline & Mean & Std. Dev. & Mean & Std. Dev. & Mean & Std. Dev. & Mean & Std. Dev. \\
\hline Economic factors & 63.7 & 21.316 & 63.7 & 19.048 & 68.7 & 21.377 & 64.0 & 25.146 \\
\hline Environmental factors & $15.9^{* *}$ & 13.514 & $15.5^{* *}$ & 10.560 & 14.5 & 13.016 & $14.2^{* *}$ & 13.678 \\
\hline Social factors & $20.4^{* *}$ & 14.471 & $20.8^{* *}$ & 13.327 & 16.7 & 12.789 & $21.7^{* *}$ & 18.528 \\
\hline
\end{tabular}

Hypothesis 3 concerns the relative importance of the factors, on the assumption that the social factor is dominant over the environmental factor. According to the descriptive analysis, on every tier, the social factor had a larger impact on the decision making of the firms than the environmental factor (Table 2). On three tiers (retail, M1 and M2), these differences remained statistically significant following paired samples t-test. The difference was statistically significant on the 0.01 level in all the other comparisons with the exception of M1 when it was significant on the 0.05 level. Thus, Hypothesis 3 was supported.

The second-highest factor on all the tiers was the social factor, ranging from 16.74 percent on the wholesale tier to 21.75 percent on the retail tier. Regardless of the amount of attention they have attracted recently, environmental factors ranked the lowest of the triple bottom line on all tiers of the supply chain, with a $14.2-15.9 \%$ share in the decision making.

\section{Discussion and Conclusions}

\subsection{Theoretical Implications}

Complementing existing research that has focused mainly on environmental sustainability, e.g., $[5,7,33,81]$, we tested the role of supply chain position and unabsorbed organisational slack on three dimensions of sustainability, namely economic, environmental and social, and provided insights on the relative importance of the three dimensions in strategic decision making. We accomplished this by examining self-reported survey data and objective financial data from 508 Finnish manufacturing and trading firms. The firms were divided into four positions in the supply chain: manufacturers of raw materials and components (M1), manufacturers of end products (M2), wholesalers (W) and retailers (R).

Our first contribution comes to the fore in investigating the relative importance of three dimensions of sustainability. While these dimensions are used in countless articles, their relative importance vis-à-vis each other remains largely unstudied [21,29]. This study provides first insights of empirical evidence on how the various areas of sustainability are perceived and valued in strategic decision making on different tiers of the supply chain. While previous research has mostly focused on large, listed companies, our sample contains firms ranging from micro-sized to large multinationals, and thus the results also contribute to the less studied context of sustainability in SMEs [82]. Our results show that economic considerations dominate decision making, despite the growing public awareness of sustainable development. The tensions and trade-offs between economic, environmental and social objectives cannot be denied, despite the idealistic representation of sustainability in strategic decision making as a balance with equal importance between the three dimensions e.g., [83]. To provide a graphical illustration of our results, we follow the idea of Sustainable Aotearoa New Zealand [84] and depict sustainability as a Mickey Mouse model (Figure 2), with environmental and social considerations playing subsidiary roles. This finding supports one of the central arguments of Gold and Schleper [2] who criticise firms for following instrumental logic according to which economic sustainability supersedes environmental and social considerations. If firms focus only on practices that are economically beneficial, they will not be able to mitigate all their negative social and environmental impacts and hence cannot be truly sustainable [85]. 


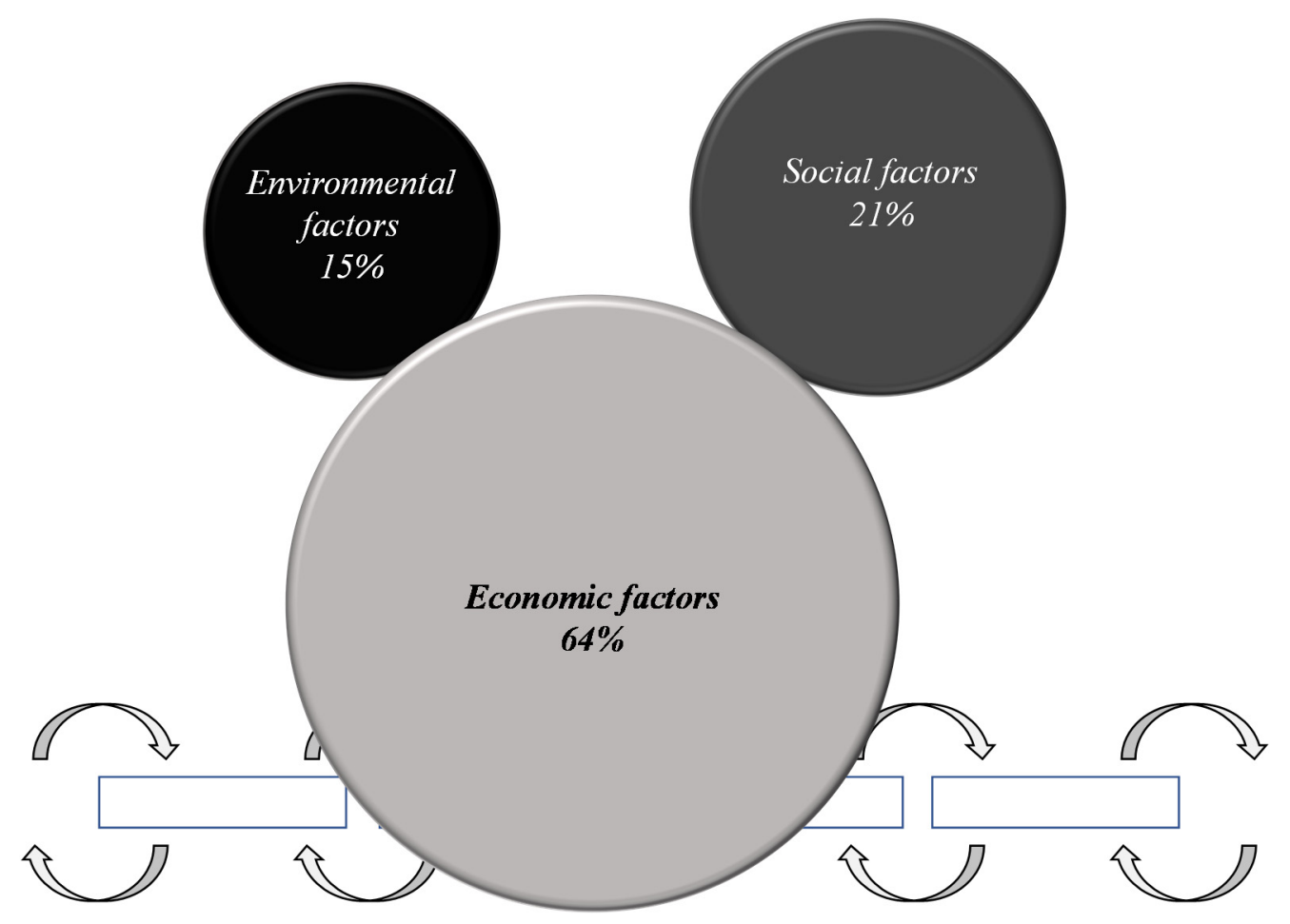

Figure 2. Mickey Mouse unravelled: the relative importance of economic, environmental and social dimensions of sustainability.

We also viewed the importance of each dimension of sustainability through the stakeholder theory and analysed if a firm's position in the supply chain affects the importance of each dimension of sustainability and thereby contribute to the literature on multi-tier supply chain management. We hypothesised that the importance of the economic dimension of sustainability in decision making would grow towards the upstream of the supply chain $(\mathrm{H} 2)$, mainly because of financial pressures from their customers and lack of incentives for improving environmental and social performance $[5,55,58]$. Contrary to expectations, there were no statistically significant differences in importance in mid- to long-term decision making on the economic dimension among the four positions in the supply chain. In other words, position in the supply chain does not seem to affect the importance of the sustainability dimensions. One explanation for this may be supply chain collaboration and pressures exerted by supply chain partners. Recent research has suggested a green contagion effect [53], whereby the stakeholder pressures propagate sustainability practices along the supply chain. Furthermore, supply chain collaboration between buyers and suppliers develops sustainability capabilities all the way to the upstream [86]. Because of this supply chain contagion, the importance of sustainability may be aligned across the multi-tier supply chain.

The results confirmed that social sustainability was more important than environmental sustainability in mid-to-long-term decision making (H3). There was a statistically significant difference between environmental and social sustainability among M1 and M2 manufacturers and retailers, but there was no difference on the wholesale tier. This finding runs somewhat counter to some of the previous research implying that environmental considerations receive more attention [20]. Nevertheless, this finding aligns with recent research, indicating that social sustainability criteria had a stronger impact on consumers and purchasing managers' willingness to pay for a product [63,64]. This may be because environmental issues have a larger psychological distance from supply chain decision makers than social issues and are therefore less likely to induce a behavioural change $[11,66,67]$.

Our second main contribution provides insights on unabsorbed slack as an antecedent to sustainability. While previous research has often focused on the relationship between 
environmental and economic performance and relied on their simultaneous measurement $[22,26]$, we investigate organisational slack as a driver of all three sustainability dimensions and analyse objective 3-year financial data. The results partly support our hypotheses. As expected, unabsorbed organizational slack was negatively related to the importance of the economic dimension of sustainability (H1a). This finding implies that firms with limited resources are more likely to use their scarce resources for profit generation and earning adequate returns and to delay investments to environmental and social sustainability improvements, as also suggested by Chiu and Sharfman [9].

Equally, our findings suggest that unabsorbed organizational slack is positively related to the importance of environmental sustainability but not social sustainability (H1b). In other words, firms with excessive resources are able to behave in a more idealistic way and engage more in environmental sustainability. In terms of social sustainability, such a link was not statistically significant. One reason for this might again relate to the concept of psychological distance, implying that issues that are perceived as close are more easily acted upon [65]. Committed and healthy employees are an important asset to firms, and mistreating them quickly leads to undesired outcomes, such as lawsuits, resignations and a bad corporate reputation [87]. Hence, even firms with limited resources go to great lengths to ensure employee welfare. When it comes to slack resources and environmental sustainability, our findings indicate that there is a group of firms that can be characterised as "prosperous visionaries". These firms may perceive environmental sustainability as a way of "doing well by doing good" [37] and can afford to do so. Yet, based on the dominance of economic criteria in strategic decision making, as demonstrated by our results, instrumental logic is still likely to be the prevailing mindset.

Authors should discuss the results and how they can be interpreted from the perspective of previous studies and of the working hypotheses. The findings and their implications should be discussed in the broadest context possible. Future research directions may also be highlighted.

\subsection{Managerial and Societal Implications}

The results of the study carry managerial and societal implications. It seems, for example, that economic criteria dominate the decision making in firms. Hence, both environmental and social sustainability should be more strongly combined and balanced with economic performance (i.e., in making a business case) to encourage firms to change their behaviour. This finding is hardly surprising given that the primacy of profits is defined by law in many countries. Therefore, even if more and more firms are rethinking their business models, profit generation remains as a central role.

An important question for policy makers is how to reduce the perceived psychological distance of environmental issues. However, market pressures may demand to become more environmentally and socially sustainable in the longer run, not least to be able to respond to growing pressures and to generate profits. This means that "prosperous visionaries" will be able to set the standard and influence the environmental and social sustainability initiatives of other firms and their supply chains to a considerable extent. From a consumer's point of view, it would be important to make the action and inaction visible. For example, when "prosperous visionaries" set an example by calculating and publicly showing the carbon footprint of their products, those who can afford may need to follow the lead to remain in competition. This means that firms with less resources are in danger of losing the game.

\subsection{Limitations and Future Research}

This research was based on a survey setup, with coverage limited to a single country. Given that most supply chains are international, a larger geographical coverage would validate the results. The sustainability measures used give a rather simplistic view of the concepts under study. Even if sustainability is a widely accepted concept, the measures still leave room for interpretation. For example, while a firm may not be concerned about human rights issues in its supply chains, it may place a high emphasis on the well-being 
of its own employees. Future research should therefore divide sustainability dimensions into more detailed items to elucidate potential variance within each dimension. It could be expected that if an upstream firm is a part of supply chain with a powerful lead firm, they may face more pressure for sustainability. These limitations provide a natural path for further research. Given that we did not find a clear linkage between a firm's position in a linear supply chain, it could be fruitful to study large-scale supply networks to investigate if centrality and connectedness would be better predictors of sustainability priorities. The equal importance of sustainability in decision making might also be caused by the so-called "green contagion effect" $[7,53]$, and hence it would be interesting to study what kinds of mechanisms are used to propagate sustainability upstream.

Moreover, the role of organisational slack should be studied further, preferably with a longer time period. The outbreak of the COVID-19 pandemic may have changed the paradigms and priorities in firms and supply chains. Future work could investigate this potential change in the relative importance of the three sustainability dimensions. While this study analysed only one-directional causality between economic sustainability and the two other dimensions, exploring the factors that help creating a virtuous cycle is an aspect in need of additional contributions.

Author Contributions: Conceptualization, S.L., T.S., A.B., J.T. and L.O.; methodology, S.L., T.S. and J.T.; formal analysis, S.L. and T.S.; data curation, T.S.; writing-original draft preparation, S.L., T.S. and A.B.; writing-review and editing, S.L.; visualization, T.S. and J.T.; project administration, L.O. and T.S. All authors have read and agreed to the published version of the manuscript.

Funding: This research received no external funding.

Institutional Review Board Statement: Not applicable.

Informed Consent Statement: Informed consent was obtained from all subjects involved in the study.

Data Availability Statement: The data that support the findings of this study are available on request from the corresponding author. The data are not publicly available due to containing information that could compromise the privacy of research participants.

Conflicts of Interest: The authors declare no conflict of interest. 


\section{Appendix A}

\begin{tabular}{ll} 
Manufacture of... & $\begin{array}{l}\text { Number of } \\
\text { firms }\end{array}$ \\
\hline food products & 28 \\
beverages & 3 \\
textiles & 1 \\
wearing apparel & 2 \\
leather and related products & 1 \\
wood and of products of wood and cork, except furniture; articles & \\
of straw and plaiting materials & 24 \\
paper and paper products & 7 \\
Printing and reproduction of recorded media & 3 \\
chemicals and chemical products & 22 \\
rubber and plastic products & 7 \\
other non-metallic mineral products & 2 \\
basic metals & 5 \\
fabricated metal products, except machinery and equipment & 64 \\
computer, electronic and optical products & 9 \\
electrical equipment & 9 \\
machinery and equipment n.e.c. & 26 \\
motor vehicles, trailers and semi-trailers & 2 \\
other transport equipment & 4 \\
furniture & 10 \\
Other manufacturing & 25 \\
Repair and installation of machinery and equipment & 24 \\
\hline Retail and & \\
\hline
\end{tabular}

Retail and wholesale

Sale of motor vehicles

Maintenance and repair of motor vehicles 11

Sale of motor vehicle parts and accessories 11

Wholesale on a fee or contract basis 13

Wholesale of foo, beverages and tobacco 9

Wholesale of household goods 2

Wholesale of information and communication equipment 6

Wholesale of other machiner, equipment and supplies 19

Other specialised wholesale $\quad 34$

Non-specialised wholesale trade $\quad 8$

Retail sale in non-specialised stores 11

Retail sale of fodo, beverages and tobacco in specialised stores $\quad 7$

Retail sale of automotive fuel in specialised stores 4

Retail sale of information and communication equipment in specialis 5

Retail sale of other household equipment in specialised stores 3

Retail sale of cultural and recreation goods in specialised stores $\quad 6$

Retail sale of other goods in specialised stores $\quad 61$

Retail trade not in store, stalls or markets 14

Figure A1. Industry Composition of the Sample. 


\section{References}

1. Slawinski, N.; Bansal, P. Short on time: Intertemporal tensions in business sustainability. Organ. Sci. 2015, 26, 531-549. [CrossRef]

2. Gold, S.; Schleper, M.C. A pathway towards true sustainability: A recognition foundation of sustainable supply chain management. Eur. Manag. J. 2017, 35, 425-429. [CrossRef]

3. Xiao, C.; Wilhelm, M.; van der Vaart, T.; van Donk, D.P. Inside the buying firm: Exploring responses to paradoxical tensions in sustainable supply chain management. J. Supply Chain Manag. 2019, 55, 3-20. [CrossRef]

4. Hosta, M.; Zabkar, V. Antecedents of environmentally and socially responsible sustainable consumer behaviour. J. Bus. Ethics 2021, 171, 273-293. [CrossRef]

5. Schmidt, C.G.; Foerstl, K.; Schaltenbrandt, B. The supply chain position paradox: Green practices and firm performance. J. Supply Chain Manag. 2017, 53, 3-25. [CrossRef]

6. Waddock, S.A.; Graves, S.B. The corporate social performance-financial performance link. Strateg. Manag. J. 1997, 18, 303-319. [CrossRef]

7. Lee, S.Y.; Klassen, R.D.; Furlan, A.; Vinelli, A. The green bullwhip effect: Transferring environmental requirements along a supply chain. Int. J. Prod. Econ. 2014, 156, 39-51. [CrossRef]

8. Hartmann, J.; Moeller, S. Chain liability in multitier supply chains? Responsibility attributions for unsustainable supplier behaviour. J. Oper. Manag. 2014, 32, 281-294. [CrossRef]

9. Chiu, S.; Sharfman, M. Legitimacy, visibility, and the antecedents of corporate social performance: An investigation of the instrumental perspective. J. Manag. 2009, 37, 1558-1585. [CrossRef]

10. Turker, D.; Altuntas, C. Sustainable supply chain management in the fast fashion industry: An analysis of corporate reports. Eur. Manag. J. 2014, 32, 837-849. [CrossRef]

11. Busse, C.; Kach, A.P.; Bode, C. Sustainability and the false sense of legitimacy: How institutional distance augments risk in global supply chains. J. Bus. Logist. 2016, 37, 312-328. [CrossRef]

12. Clarke, T.; Boersma, M. The governance of global value chains: Unresolved human rights, environmental and ethical dilemmas in the Apple supply chain. J. Bus. Ethics 2017, 143, 111-131. [CrossRef]

13. Leyva-de la Hiz, D.I.; Ferron-Vilchez, V.; Aragon-Correa, J.A. Do firms' slack resources influence the relationship between focused environmental innovations and financial performance? More is not always better. J. Bus. Ethics 2019, 159, 1215-1227. [CrossRef]

14. Symeou, P.C.; Zyglidopoulos, S.; Gardberg, N.A. Corporate environmental performance: Revisiting the role of organizational slack. J. Bus. Res. 2019, 96, 169-182. [CrossRef]

15. Singh, J.V. Performance, slack, and risk taking in organizational decision making. Acad. Manag. J. 1986, $29,562-585$.

16. Wiengarten, F.; Fan, D.; Lo, C.K.; Pagell, M. The differing impacts of operational and financial slack on occupational safety in varying market conditions. J. Oper. Manag. 2017, 52, 30-45. [CrossRef]

17. Shafiq, A.; Ahmed, M.U.; Mahmoodi, F. Impact of supply chain analytics and customer pressure for ethical conduct on socially responsible practices and performance: An exploratory study. Int. J. Prod. Econ. 2020, 225, 107571. [CrossRef]

18. Wilhelm, M.; Blome, C.; Wieck, E.; Xiao, C.Y. Implementing sustainability in multi-tier supply chains: Strategies and contingencies in managing sub-suppliers. Int. J. Prod. Econ. 2016, 182, 196-212. [CrossRef]

19. Sauer, P.C.; Seuring, S. Extending the reach of multi-tier sustainable supply chain management-Insights from mineral supply chains. Int. J. Prod. Econ. 2019, 217, 31-43. [CrossRef]

20. Yawar, S.; Seuring, S. Management of social issues in supply chains: A literature review exploring social issues, actions and performance outcomes. J. Bus. Ethics 2017, 141, 621-643. [CrossRef]

21. Choi, S.; Ng, A. Environmental and economic dimensions of sustainability and price effects on consumer responses. J. Bus. Ethics 2011, 104, 269-282. [CrossRef]

22. Endrikat, J.; Guenther, E.; Hoppe, H. Making sense of conflicting empirical findings: A meta-analytic review of the relationship between corporate environmental and financial performance. Eur. Manag. J. 2014, 32, 735-751. [CrossRef]

23. Guo, F.; Zou, B.; Zhang, X.; Bo, Q.; Li, K. Financial slack and firm performance of SMMEs in China: Moderating effects of government subsidies and market-supporting institutions. Int. J. Prod. Econ. 2019, 223, 107530. [CrossRef]

24. Busch, T.; Friede, G. The Robustness of the Corporate Social and Financial Performance Relation: A Second-Order Meta-Analysis. Corp. Soc. Responsib. Environ. Manag. 2018, 25, 583-608. [CrossRef]

25. Fang, C.; Zhang, J. Performance of green supply chain management: A systematic review and meta analysis. J. Clean. Prod. 2018, 183, 1064-1081. [CrossRef]

26. Hang, M.; Geyer-Klingeberg, J.; Rathgeber, A.W. It is merely a matter of time: A meta-analysis of the causality between environmental performance and financial performance. Bus. Strategy Environ. 2018, 28, 257-273. [CrossRef]

27. Lahouel, B.B.; Gaies, B.; Zaied, Y.B.; Jahmane, A. Accounting for endogeneity and the dynamics of corporate social-corporate financial performance relationship. J. Clean. Prod. 2019, 230, 352-364. [CrossRef]

28. Freeman, R.E. Strategic Management: A Stakeholder Approach; Pittman Publishing: Boston, MA, USA, 1984.

29. Meixell, M.J.; Luoma, P. Stakeholder pressure in sustainable supply chain management: A systematic review. Int. J. Phys. Distrib. Logist. Manag. 2015, 45, 69-89. [CrossRef]

30. Wu, Z.; Ellram, L.M.; Schuchard, R. Understanding the Role of Government and Buyers in Supplier Energy Efficiency Initiatives. J. Supply Chain Manag. 2014, 50, 84-105. [CrossRef] 
31. Mitchell, R.K.; Agle, B.R.; Wood, D.J. Toward a theory of stakeholder identification and salience: Defining the principle of who and what really counts. Acad. Manag. Rev. 1997, 22, 853-886. [CrossRef]

32. Busse, C.; Schleper, C.; Weilenmann, J.; Wagner, S.M. Extending the supply chain visibility boundary: Utilizing stakeholders for identifying supply chain sustainability risks. Int. J. Phys. Distrib. Logist. Manag. 2017, 47, 18-40. [CrossRef]

33. Seles, B.M.R.P.; Jabbour, A.B.L.D.S.; Jabbour, C.J.C.; Dangelico, R.M. The green bullwhip effect, the diffusion of green supply chain practices, and institutional pressures: Evidence from the automotive sector. Int. J. Prod. Econ. 2016, 182, 342-355. [CrossRef]

34. Jazairy, A.; von Haartman, R. Analysing the institutional pressures on shippers and logistics service providers to implement green supply chain management practices. Int. J. Logist. Res. Appl. 2020, 23, 44-84. [CrossRef]

35. Donaldson, T.; Preston, L.E. The stakeholder theory of the corporation: Concepts, evidence, and implications. Acad. Manag. Rev. 1995, 20, 65-91. [CrossRef]

36. De Gooyert, V.; Rouwette, E.; van Kranenburg, H.; Freeman, E. Reviewing the role of stakeholders in Operational Research: A stakeholder theory perspective. Eur. J. Oper. Res. 2017, 262, 402-410. [CrossRef]

37. Busse, C. Doing Well by Doing Good? The Self-interest of Buying Firms and Sustainable Supply Chain Management. J. Supply Chain Manag. 2015, 52, 28-47. [CrossRef]

38. Hofmann, H.; Busse, C.; Bode, C.; Henke, M. Sustainability-related supply chain risks: Conceptualization and management. Bus. Strategy Environ. 2014, 23, 160-172. [CrossRef]

39. Lo, S.M. Effects of supply chain position on the motivation and practices of firms going green. Int. J. Oper. Prod. Manag. 2013, 34, 93-114. [CrossRef]

40. Van Tulder, R.; van Wijk, J.; Kolk, A. From chain liability to chain responsibility. J. Bus. Ethics 2009, 85, 399-412. [CrossRef]

41. Touboulic, A.; Chicksand, D.; Walker, H. Managing Imbalanced Supply Chain Relationships for Sustainability: A Power Perspective. Decis. Sci. 2014, 45, 577-619. [CrossRef]

42. Voss, G.B.; Sirdeshmukh, D.; Voss, Z.G. The effects of slack resources and environmental threat on product exploration and exploitation. Acad. Manag. J. 2008, 51, 147-164. [CrossRef]

43. Tan, J.; Peng, M.W. Organizational slack and firm performance during economic transitions: Two studies from an emerging economy. Strateg. Manag. J. 2003, 24, 1249-1263. [CrossRef]

44. Testa, M.; D'Amato, A. Corporate environmental responsibility and financial performance: Does bidirectional causality work? Empirical evidence from the manufacturing industry. Soc. Responsib. J. 2017, 13, 221-234. [CrossRef]

45. Alexopoulos, I.; Kounetas, K.; Tzelepis, D. Environmental and financial performance. Is there a win-win or a win-loss situation? Evidence from the Greek manufacturing. J. Clean. Prod. 2018, 197, 275-1283. [CrossRef]

46. Xu, E.; Yang, H.; Quan, J.M.; Lu, Y. Organizational slack and corporate social performance: Empirical evidence from China's public firms. Asia Pac. J. Manag. 2014, 32, 181-198. [CrossRef]

47. Chen, H.; Zeng, S.; Lin, H.; Ma, H. Munificence, dynamism, and complexity: How industry context drives corporate sustainability. Bus. Strategy Environ. 2017, 26, 125-141. [CrossRef]

48. Staudenmayer, N.; Tyre, M.; Perlow, L. Time to Change: Temporal Shifts as Enablers of Organizational Change. Organ. Sci. 2002, 13, 583-597. [CrossRef]

49. Duque-Grisales, E.; Aguilera-Caracuel, J. Environmental, social and governance (ESG) scores and financial performance of Multilatinas: Moderating effects of geographic international diversification and financial slack. J. Bus. Ethics 2021, 168, 315-334. [CrossRef]

50. Vanacker, T.; Collewaert, V.; Zahra, S.A. Slack resources, firm performance, and the institutional context: Evidence from privately held European firms. Strateg. Manag. J. 2017, 38, 1305-1326. [CrossRef]

51. Lin, W.L.; Ho, J.A.; Leong, L.W.; Lee, C. Does corporate social responsibility lead to improved firm performance? The hidden role of financial slack. Soc. Responsib. J. 2019, 16, 957-982. [CrossRef]

52. Gao, L.; Wang, J.; He, H.; Wang, S. Do motives contribute to sustainable supply chain management? A Motive-AbilityOpportunity triangle research perspective. Int. J. Logist. Res. Appl. 2021, 1-15. [CrossRef]

53. Mena, C.; Schoenherr, T. The green contagion effect: An investigation into the propagation of environmental practices across multiple supply chains tiers. Int. J. Prod. Res. 2020, 1-18. [CrossRef]

54. Elking, I.; Paraskevas, J.P.; Grimm, C.; Corsi, T.; Adams, S. Financial dependence, lean inventory strategy, and firm performance. J. Supply Chain Manag. 2017, 53, 22-38. [CrossRef]

55. Lanier, D., Jr.; Wempe, W.F.; Swink, M. Supply chain power and real earnings management: Stock market perceptions, financial performance effects, and implications for suppliers. J. Supply Chain Manag. 2019, 55, 48-70. [CrossRef]

56. Lorentz, H.; Solakivi, T.; Töyli, J.; Ojala, L. Trade credit dynamics during the phases of the business cycle-A value chain perspective. Supply Chain Manag. Int. J. 2016, 21, 363-380. [CrossRef]

57. Gereffi, G.; Lee, J. Why the World Suddenly Cares About Global Supply Chains. J. Supply Chain Manag. 2012, 48, 24-32. [CrossRef]

58. Schleper, M.C.; Blome, C.; Wuttke, D.A. The dark side of buyer power: Supplier exploitation and the role of ethical climates. J. Bus. Ethics 2017, 140, 97-114. [CrossRef]

59. Brockhaus, S.; Kersten, W.; Knemeyer, A.M. Where do we go from here? Progressing sustainability implementation efforts across supply chains. J. Bus. Logist. 2013, 34, 167-182. [CrossRef]

60. Hahn, T.; Figge, F.; Pinkse, J.; Preuss, L. Trade-offs in corporate sustainability: You can't have your cake and eat it. Bus. Strategy Environ. 2010, 19, 217-229. [CrossRef] 
61. Oberhofer, P.; Dieplinger, M. Sustainability in the Transport and Logistics Sector: Lacking Environmental Measures. Bus. Strategy Environ. 2013, 23, 236-253. [CrossRef]

62. Rogers, Z.S.; Carter, C.R.; Kwan, V. Making tough choices: A policy capturing approach to evaluating the tradeoffs in sustainable supplier development initiatives. J. Purch. Supply Manag. 2019, 25, 100574. [CrossRef]

63. Goebel, P.; Reuter, C.; Pibernik, R.; Sichtmann, C.; Bals, L. Purchasing managers' willingness to pay for attributes that constitute sustainability. J. Oper. Manag. 2018, 62, 44-58. [CrossRef]

64. Nichols, B.S.; Stolze, H.; Kirchoff, J.F. Spillover effects of supply chain news on consumers' perceptions of product quality: An examination within the triple bottom line. J. Oper. Manag. 2019, 65, 536-559. [CrossRef]

65. Trope, Y.; Liberman, N. Construal-level theory of psychological distance. Psychol. Rev. 2010, 117, 440-463. [CrossRef] [PubMed]

66. Trope, Y.; Liberman, N. Temporal construal. Psychol. Rev. 2003, 110, 403. [CrossRef] [PubMed]

67. Spence, A.; Poortinga, W.; Pidgeon, N. The Psychological Distance of Climate Change. Risk Anal. 2011, 32, 957-972. [CrossRef]

68. Carter, C.R.; Hatton, M.R.; Wu, C.; Chen, X. Sustainable supply chain management: Continuing evolution and future directions. Int. J. Phys. Distrib. Logist. Manag. 2019, 50, 122-146. [CrossRef]

69. Catlin, J.R.; Luchs, M.G.; Phipps, M. Consumer perceptions of the social vs. environmental dimensions of sustainability. J. Consum. Policy 2017, 40, 245-277. [CrossRef]

70. Olkkonen, L.; Quarshie, A. (Eds.) The dawn of stakeholder thinking in Nordic countries. In Corporate Social Responsibility in Finland: Origins, Characteristics, and Trends; Palgrave Pivot: Cham, Switzerland, 2019.

71. Solakivi, T.; Ojala, L.; Laari, S.; Lorentz, H.; Kiiski, T.; Töyli, J.; Malmsten, J.; Bask, A.; Rintala, O.; Paimander, A.; et al. Finland State of Logistics 2018; E-2:2018; Publications of Turku School of Economics: Turku, Finland, 2018.

72. Wagner, S.M.; Kemmerling, R. Handling nonresponse in logistics research. J. Bus. Logist. 2010, 31, 357-381. [CrossRef]

73. Midmore, P.; Munday, M.; Roberts, A. Assessing industry linkages using regional input-output tables. Regul. Stud. 2006, 40, 329-343. [CrossRef]

74. Hautala, P.; Lorentz, H.; Töyli, J. Value chain perspective on the use of trade credit during the 2006-2015 business cycle-Evidence from Eurozone SMEs. Int. J. Logist. Res. Appl. 2019, 22, 204-227. [CrossRef]

75. Jones, L.P. The Measurement of Hirschmanian Linkages. Q. J. Econ. 1976, 90, 323-333. [CrossRef]

76. Bergkvist, L.; Rossiter, J.R. The predictive validity of multiple-item versus single-item measures of the same constructs. J. Mark. Res. 2007, 44, 175-184. [CrossRef]

77. Podsakoff, P.M.; MacKenzie, S.B.; Lee, J.; Podsakoff, N.P. Common method biases in behavioral research: A critical review of the literature and recommended remedies. J. Appl. Psychol. 2003, 88, 879-903. [CrossRef]

78. Marshall, D.; McCarthy, L.; Heavey, C.; McGrath, P. Environmental and social supply chain management sustainability practices: Construct development and measurement. Prod. Plan. Control 2015, 26, 673-690. [CrossRef]

79. Mani, V.; Agarwal, R.; Gunasekaran, A.; Papadopoulos, T.; Dubey, R.; Childe, S.J. Social sustainability in the supply chain: Construct development and measurement validation. Ecol. Indic. 2016, 71, 270-279. [CrossRef]

80. European Commission. Commission Recommendation of 6 May 2003 Concerning the Definition of Micro, Small and MediumSized Enterprises. 2003. Available online: https://eur-lex.europa.eu/legal-content/EN/TXT/?uri=CELEX:32003H0361 (accessed on 25 November 2021).

81. Bellamy, M.A.; Dhanorkar, S.; Subramanian, R. Administrative environmental innovations, supply network structure, and environmental disclosure. J. Oper. Manag. 2020, 66, 895-932. [CrossRef]

82. Stekelorum, R. The roles of SMEs in implementing CSR in supply chains: A systematic literature review. Int. J. Logist. Res. Appl. 2019, 23, 228-253. [CrossRef]

83. Carter, C.R.; Rogers, D.S. A framework of sustainable supply chain management: Moving toward new theory. Int. J. Phys. Distrib. Logist. Manag. 2008, 38, 360-387. [CrossRef]

84. Sustainable Aotearoa New Zealand Inc. (SANZ). Strong Sustainability for New Zealand, Principles and Scenarios. Available online: https:/ / nwo.org.nz/resources/strong-sustainability-for-new-zealand-principles-and-scenarios / (accessed on 25 November 2021).

85. Pagell, M.; Shevchenko, A. Why research in sustainable supply chain management should have no future. J. Supply Chain Manag. 2014, 50, 44-55. [CrossRef]

86. Tachizawa, E.M.; Wong, C.Y. Towards a theory of multi-tier sustainable supply chains: A systematic literature review. Supply Chain Manag. Int. J. 2014, 19, 643-663. [CrossRef]

87. Pfeffer, J. Building sustainable organizations: The human factor. Acad. Manag. Perspect. 2010, 24, 34-45. 